\title{
EDUCATIONAL PROCESS IN GEOGRAPHY SPECIFICS AND PROSPECTS
}

DOI: http://dx.doi.org/10.18509/GBP.2018.67

UDC: 37:91(497.2)

\author{
Maya Vasileva \\ Sofia University "St. Kliment Ohridski", Faculty of Geology and Geography, Bulgaria
}

\begin{abstract}
The main problem in contemporary geography didactics is the demand for quality and efficiency of the geography educational process. The topicality of this issue is conditioned by the requirements of Bulgarian society towards geographic cognition and knowledge and improving individual's ability for successful social and professional adaptation and realization. These needs call for changes in geography educational process, mainly aimed at creating conditions for the transformation of geographic information into knowledge, skills, competences and patterns of personality that are relevant to the life and activity of the students. Considering the mentioned facts, the paper reveals the specifics of modern educational process in geography and outlines the perspective for its development.
\end{abstract}

Keywords: geography, geography didactics, learning process

Modern geography education evolves into "new realities" and experiences serious pressure from ever-increasing public needs and expectations. This is due to a number of factors of a different nature, scale and mode of influence: political, social and economic, global educational trends, new scientific orientations and concepts, impact of higher technologies and communications, changed personal attitudes and values. In this respect, the new realities are a serious challenge and they require important changes in the nature of geography education thus focusing attention and efforts on different research positions. Searching for quality and efficiency of geography education always goes through the geography educational process. And this is quite natural, since it establishes the conditions for transforming geographic information into knowledge, skills, competences and patterns of behavior that are of great significance to the life and activity of the student, namely "the means of achieving public and personal effectiveness" [5]. In relation to the above, the aims of this paper are:

- to reveal the specifics of the modern educational process in geography;

- to outline the prospects for its development.

Generally speaking, under educational process is meant the act of real interaction between the teacher and the pupils in a specific (local) environment and on the basis of specific learning content to achieve certain goals [3], [4].

The analysis of this definition focuses on several specifics of the educational process, namely:

- real interaction between the two subjects in a specific (local) environment;

- interaction based on specific learning content;

- interaction aimed at achieving certain goals [5]. 
Therefore, the search for quality and efficiency of the educational process goes through a thorough study of the interaction. We present the interaction between the subjects using the Iceberg Model [2] (Fig. 1 and Fig. 2).

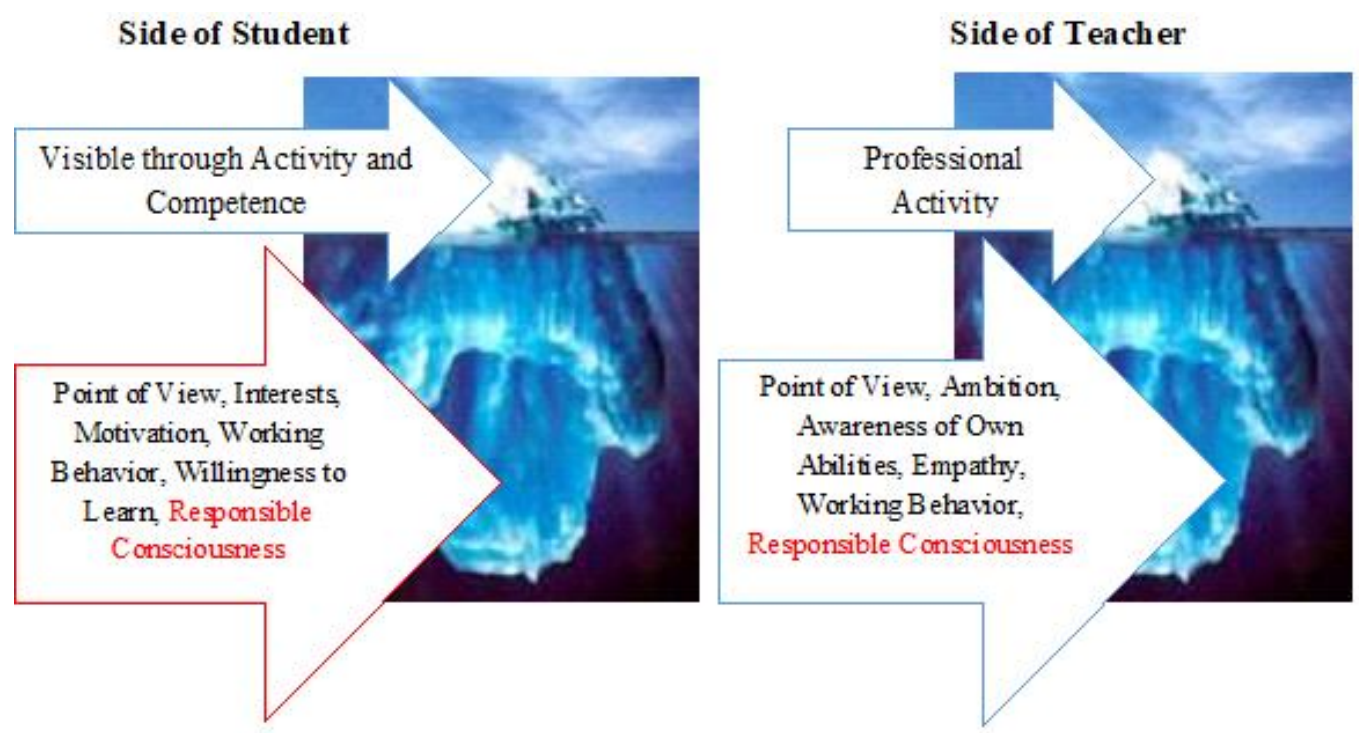

Figure 1. The two sides of the „Iceberg model“"

We use precisely this model because it reveals some basic considerations:

- Personal characteristics remain hidden but they should be explored more thoroughly as they inevitably affect the apparent competence of students.

- The teacher influence is aimed at building the competence of the pupils but it is also directed towards their personal traits.

- The interests, motivation and active attitude of students are the essential prerequisite for achieving the objectives of the interaction.

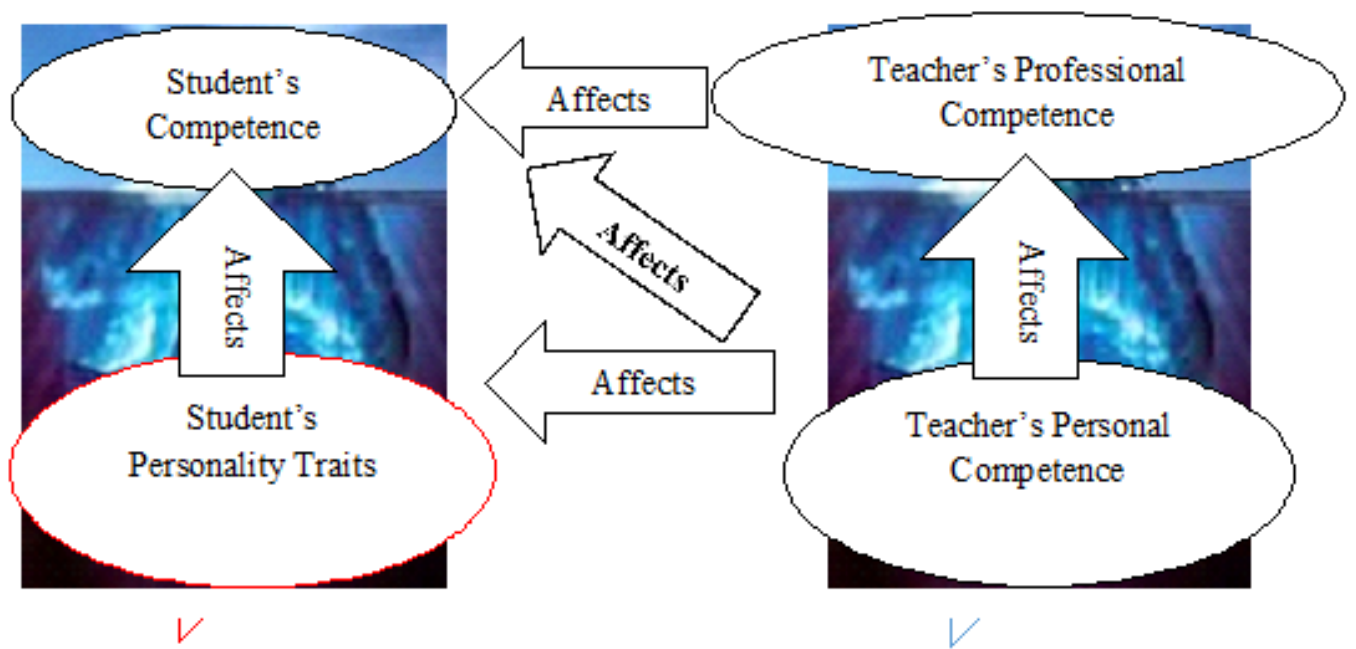

Figure 2. Influences in the „Iceberg Model“

So in the context of geography education, this means that the educational process in geography should develop on the basis of the interests, motivation and active attitude of the students. This implies the purposefulness of the activity and the clear stated attitude towards geographic learning content. 
Given that the goal of geography education is to shape the pupils' geographic culture [1], [6], development of their literacy, competence, model of behavior and value orientation, the educational process in geography should focus on:

- stimulating the cognitive activity of students;

- wide application of an active approach;

- problem centered education;

- increased student activity;

- reflection and self-reflection.

In our opinion, the development of the educational process focused on these highlights implies higher quality and efficiency.

The problem centered educational process in geography is conditioned by the developing nature of the training, the need to develop the cognitive and creative abilities of the students. Practically, it is achieved by problem solving and problematic tasks and helps to overcome the passive perception, memorization and simple reproduction of the curriculum. And it is done through:

- learning situations purposefully organized by teacher which are related to resolution of studied problems and for which the available students' knowledge and experience is insufficient; situations requiring "learning by discovery";

- pre-selection of problems and facts by the teacher that involves pupils in intellectual difficulty and the overcoming of which leads to "new knowledge and new experience";

- interaction between the teacher and the pupils with active participation of the latter in the "simulated" by the teacher research process;

- curriculum selection in which the contradictions in geography science are shown; the contradictions between pupils' life perceptions and scientific geographic knowledge become evident; to choose and discuss the main problems of geography science and the ways of solving them; to adopt the methods through which problem centered training is being implemented [5].

In current paper as specifics of geography educational process are acknowledged:

- the applied geographic principles of learning and training (to explore your homeland and local neighbourhood/community);

- geographical training methods (cartography and GIS, field study and trips, scientific research);

- geographic approaches to scientific knowledge (typological, regional, integrated).

The nature of the modern geography educational process is also the enhancement of the integrative tendencies and the implementation of the integrated approach. We should emphasize its role as a tool for implementing systematicity in the objectives, content and organization of educational process, and its usage at both levels - subject (geography) and inter-subject (geography and other sciences).

The search for a new quality of the educational process draws attention to its humanization, socialization and technology provision. The humanization is associated with:

- positioning the students with their needs and interests at the center of the educational process;

- establishing the new roles of teacher and pupils based on partnership and cooperation between them;

- managing the learning process based on interactivity. 
The implementation of the activities as educational technologies and their application for the achievement of the goals of geography education is a step towards its technological development [2], [3].

Learning in geography education takes place in a social environment i.e. it is a result of social relationships. The social environment changes: the organization of the interaction between the subjects; influences the selection of forms and methods by which it occurs; changes the role and behavior of the subjects; determines their mutual activity. Students learn both from the teacher and from each other. This determines socialization as a particular feature of the educational process in geography. And the evolving of information society and constant improvement of higher technologies influence the geography training through better technology provision and transforms the essence and attitude towards geography science.

The above-mentioned features of geography learning process allow us to draw some perspectives for its future development. And as such we define the following aspects:

- humanizing and validating the new roles of the two subjects (individual, active, initiative, responsible and tolerant pupils and teacher being organizer, moderator and partner);

- socializing and maintaining the communication in the learning environment (using mainly dialogue and discussions, validating the ideas and concepts, adopting decisions approved by the group);

- technology provision of learning process and the build-up of pupils' self experience (when pupils use empirical databases and then formulate independently algorithms which they afterwards follow in their actions);

- problem-centered learning process (exploring geographic content as a problem that requires solution and is subject of critical thinking and searching for alternative solutions);

- management of interaction between the subjects (teacher and pupils) - with emphasis on differentiating training process according to the individual needs and interests of the students; implementation of modern educational technologies with enhanced interaction; transition to problematic training; increasing the role of motivation, reflection and self-reflection.

\section{REFERENCES}

[1] Гайтанджиева, Р. Стратегия на географското образование в СОУ при новите реалности, София, Анубис, 2000

[2] Leisen, J. Was ist guter Unterricht? In: Magazin Hochladen, 1-15 https://www.yumpu.com/de/document/view/46739752/was-ist-guter-unterricht-josefleisen (04.12.2017)

[3] Петров, П. Дидактика, София, Веда Словена - ЖГ, 2001

[4] Радев, Пл. Обща училищна дидактика, Пловдив, УИ „П. Хилендарски”, 2005

[5] Цанкова, Л. Образователният процес по география в средното училище от позициите на конструктивизма В: Годишник на СУ, ГГФ, Кн. 2 - География, том 105 (2013), 2012, $445-452$

[6] Цанкова, Л. Ръководство по дидактика на географията, София, УИ „Св. Кл. Охридски”, 2005 